UDC: $37.091 .2-048.35: 378-021.3$

DOI: https://doi.org/10.24195/2414-4665-2017-5-3

\begin{abstract}
Doctor of Education, profession, academician of the National Academy of Educational Sciences of Ukraine, Head of the Department of Theory and Methods of Preschool Education, South Ukrainian National Pedagogical University named after K. D. Ushynsky, 26, Staroportofrankivska Str., Odessa, Ukraine
\end{abstract}

\title{
MODERN APPROACH TO THE ISSUE OF HIGHER EDUCATION MODERNIZATION
}

The paper aims to suggest and describe the main principles of higher education modernization in terms of contemporary educational space. Thus, the following principles have been distinguished: the principle of humanistic nature of education; the principle of nature compliance and nature expediency, but in its new vision; the principle of facilitation of a high level of spirituality of students' activity; the principle of future specialists' self-organizing creativity which presupposes education construction according to the synergetic approach; the principle of aware subjectivity and consciousness, according to which, both a teacher and a student are recognized as active subjects of education; the principle of subjective control; the principle of personal goal-setting which involves the implementation of elective or special courses, presence of individual curricula, distance learning, etc.; the principle of meta-subject grounds of the educational process in higher education; the principle of situativity of education, situational and pedagogical support focused on creative students in terms of teaching them in an individual way. A university teacher's task is to prevent the penetration of anti-humanistic means into the teaching / learning process of higher education with the help of humanistic principles, to demonstrate their failure (those of anti-humanistic ones) in achieving positive outcomes in their future professional activity, to convince would-be professionals of taking themselves as the highest value which will help them to re-orient themselves from the position of a passive reproducing personality into a self-organizing, creative one, into a personality who is able to fill his/her professional activity and life creativity with sense.

Keywords: high school, principles, modernization, student, higher school teacher.

\section{Introduction}

It is worldwide known that education is a product of society the character and contents of which depend on some factors: epoch, social medium, political system, etc. Therefore, people have to live through both crisis phenomena in the field of education from time to time and stable development during some periods. All these undulating phenomena within the sphere of education are accompanied by wellknown terms: generation, intensification, optimization, humanization, reforming, modernization, etc. If we deal with the development of education in our country, these processes might involve reformation, renewal, modernization connected with the change of our Governmental board, which is not, unfortunately, that stable yet.

All that the education system of Ukraine is dealing with now, including the transfer to a new credit-module system of higher education in the framework of the Bologna process, removal from our traditional one which had been formed for centuries, can be called the modernization of education. Why do we call it modernization? Let us refer to dictionaries. The root "modern" means a new style in European art which is opposed to the traditional one. Whereas the term "modernization" means rebuilding according to modern demands, renewal of some technological process in accordance with contemporary time. Nowadays, scientists in the field of higher education are to fulfil the task connected with the transfer to a completely new for our country system of university teaching techniques, which is also new for students. The first observations over students allow us to assume that the most modern and widely used terms for our students are "module", "how can one get / be awarded a module", "have you passed the module?", have you obtained the module?". Serious questions arise. Aren't we going to lose naturalness in communication within the system of "teacher - student", "student - teacher"? Don't we seem to ruin the traditional principles of higher school functioning in our country, being delighted by the immersion into the module system?

The paper aims to suggest and describe the main principles of higher education modernization in terms of contemporary educational space.

\section{Discussion}

Anyway, all categories connected with the professional pedagogical activity are stipulated by principles. We recognize these principles: the teaching principle, the principle of up-binging, the principle of organization of the teaching / learning pedagogical activity, the principle of the integral pedagogical process, the principle of sociocultural education, the principle of state policy in the field of education, etc. However, the categories of learning, up-bringing and education may have different contents and characteristics. Thus, the principles of their organization are likely to be different, too.

By the term "principle" we understand leading ideas, rules, normative requirements to the organization and realization of the teaching / learning process. Principles are combined into a corresponding integral system which 
is realized directly in the teaching-educational process of an educational establishment.

A system of principles is built at a corresponding methodological foundations or on the basis of person's outlook which includes inner contradictions. If we refer to Ya. Komensky, he considered the principle of nature expediency, around which all the other principles are built, to be that methodological ground. Let us study those principles which concern higher education.

The principle of humanistic nature of education is the leading principle of the state policy in the field of higher professional education in Ukraine, in other words it presupposes a creation of the system of teachingeducational establishments and educational curricula which "could satisfy any educational demands set by different population groups without infringing on anybody's rights to obtain education of any level" [3, p. 118].

Thus, humanization of higher education must be built on the basis of adequate principles which correspond to the general notion "humanism".

It is widely known that humanisms means a system of ideas and views concerning a person (a human being) as the highest value [3, p. 76], recognition of "boundlessness of person's abilities, his/her capability of selfimprovement, person's rights for free demonstration of his/her abilities and beliefs, approval of person's good as a criterion of social relations" [4, p. 32].

Humanistic scientific platform which is aimed at building the pedagogical activity in higher education, in some scientists' (Ye. Bondarevska, S. Kulnevich, T. Lavrikova, V. Leshchinskyi and others) opinion, must radically change its traditional contents: student's personality transfers from the zone of pedagogical influence, in other words transmission of final, closed and "absolute" knowledge, into the sphere of pedagogical interaction, open sense-motivating orients of the pedagogical activity referring to the humanistic type transmission [5, p. 66].

In this case, the organization of interaction involves the creation of three types of interaction in the process of future specialists training: "a teacher - a student", "a student - a teacher", "a student - a student". The designated interaction initiates the following new directions of the university teachers' pedagogical activity: escape from technocratic education models, help in student's personality formation as the subject of socioculture, which means the process of person's selfdevelopment, self-organization, self-realization in personal and professional life. From the viewpoint of the humanistic pedagogical activity, a university teacher must realize future professionals' mechanisms of self-defense, self-regulation, as well as survival in the modern society, reduce social tension of professional adaptation, facilitate students' consciousness regarding sense of life and self-identification in it.

Let us return to the university teacher's pedagogical activity. Which principles should he/she use while teaching future specialists?

In our opinion, the key principle is, no doubt, the principle of nature compliance and nature expediency, but in its new vision. The designated principle obtained a classical nature; it was revealed in the works of Ya. Komensky, J. J. Russo, K. Ushynsky, V. Sukhomlinsky and others.

At the modern stage, the scientists (L. Gumilyov, I. Kon, S. Kulnevich, O. Mudryk and others) correlate the principle of nature expediency with mega-factors, in other words with the influence of subtle energy and landscapeclimatic conditions on the origin and course of the moraloriented processes, which enables us to determine the dependence of the person's spiritual and moral spheres from large and small space cycles.

According to V. Pravdivtsev's theory, people's energetic re-programming occurs in the change process of small (every 500 years) and large (every 2000 years) space cycles. As a result, people's civilization obtains a new energetic programme for further 5 centuries.

A great change, which is being experienced now by people and which finished in 2002, is characterized by essential changes in spiritual and moral programmes. Every epos, as scientists note, has its own world outlook the core of which is the phenomenon "moral instinct of consciousness" (in contradistinction to the beast's one) which is predetermined by different levels of person's spirituality in accordance with the current epoch and influence of space energetics on a person. Every person has his/her own hidden spiritual needs which may manifest themselves (or may not) depending on his/her world outlook and behaviour. It is believed that gravitational changes influence directly person's subconsciousness and psyche, actualize the qualities (positive or negative) which constitute a person. If a person contributes into his/her spiritual and intellectual growth, space energetics strengthens this process or speeds it up. People who demonstrate a low level of moral instinct of consciousness, vice versa, are the subjects for activization of these animal traits: aggressiveness, cruelty, irritability, impatience, which leads to all possible kinds of crime, military conflicts, a struggle between Good and Evil, destructive social phenomena. On the one hand, people's strivings for spiritual development, acceptance of religious postulates, involvement into them alongside with their aspiration and recognition of the Highest Absolute - God - accelerate. On the other hand, aggression is activated. Lack of spirituality, immorality, crime, wars cause natural disasters: earthquakes, tsunamis, volcanoes, etc. The task of education, of all its layers is to balance this process by means of appropriate organization of the teaching / learning process. This is what we have today.

Scientists mark that supporting a young individual's personality in nature-expedient way at a higher educational institution will facilitate the development of his/her nature expedient spirituality which could determine his/her further life journey: self-organization, selfregulation, self-identification of his/her spiritual and moral formation.

The other principle of higher education modernization is facilitation of a high level of spirituality of students' activity. The aforementioned principle means stu- 
dent's ability to provide his/her further life with high moral values, to set "moral limits and regulators" which prevent from person's transfer from a young person to the utilitarian-technocratic goal [5, p. 53]. What is going on at Ukraine's establishments of higher education today in terms of future specialists' spiritual development? Unfortunately, there are no other courses but for "Religion Studies" or "Ethics". However, certain higher institutions have temples on their territories (for instance, Odessa, Ostrog, Kiev and other ones), though it is not enough. We should revise all syllabi and curricula in the framework of strengthening a great role of youth's spiritual and moral up-bringing both in the process of their learning and extra-class activities.

A university pedagogical process should contribute to the formation and manifestation of the personal structures which would allow implementation of the students' best spiritual, moral and creative qualities. In other words, higher education will achieve its aim if conditions and potential pedagogical and professional environment are created, the environment facilitating formation and development of a highly spiritual, morally educated and creative personality.

The next principle of higher education modernization - the principle of future specialists' self-organizing creativity (S. Kulnevich) - is stipulated by the latter principle and presupposes education construction according to the synergetic approach. It enables formation of students' self-organizing pedagogical and professional activities the aim and contents of which are to be turned into selfmanagement for a professional by means of synergetic guidelines and activity conditions. We should remind that synergetics is a system of self-organization, person's inner ability to cultivate in himself/herself as well as to subconstruct his/her own new qualities which are necessary for survival under any (all possible) conditions; or inner changes provided by the activity of person's consciousness structures which influence the process of knowledge acquisition by a person and his/her further development [5].

The other principle of a new type of humanistic education is "the principle of aware subjectivity and consciousness" [5, p. 54]. According to it, both a teacher and a student are recognized as active subjects of education, observers of their own inner personal structures and their revelation in "the research field" (S. Kulnevich's term) of professional and pedagogical activities. As we see, the positions of a teacher as a knowledge-bearer and a knowledge-giver have come to nothing. These are both a teacher and a student who cognize.

A. Khutorskyi calls this principle in a different way "the principle of a type unity" [8]. According to it, all impressions every soul gets (in our case - every student) and everything that comes from teachers and the whole teaching / learning process of a certain university are to be of the same type, not of different or opposite ones [8]

It generates the principle of complementarity; its essence follows the laws of dialectics according to which op- posites will never disappear by means of their elimination, otherwise by means of their cross-complement, compromise. In practice, it means substitution of a monotonous lecture as a teaching method by a dialogue, dialogical interaction, partnership of a teacher and a student in knowledge digestion. Openness of educational information for students facilitates a dialogical form of teaching / learning. Nowadays, we have all opportunities for it: computerization of education, the Internet-system, etc.

The next principle is the principle of "subjective control" $[5,6]$. We should mention that realization of all the designated principles will depend on the formation level of both university teacher's and student's subjective control. It is a person's ability to be aware of and explain a measure of his/her participation in what is going on; a level of person's understanding of his/her life essence and activity, chosen profession, conscious differentiation of inner and outer impacts on his/her personality, behaviour and outcomes of his/her activity.

There are two accepted ways of explanation to oneself (and to other people) of what is going on with us. The first one is - we try to connect it with outer circumstances, accuse someone of something: contingency, an unsuccessful day, number, non-consideration of astrologers' warnings, etc. This is an outer, external level of subjective control.

The second, inner one is an internal level of subjective control: everything that happens to us is the result of our own efforts; these are person's beliefs in the assumption that much depends upon a person himself / herself including the results of his/her activity.

Thus, the task of higher education is to form an adequate inner / internal level of students' subjective control, their abilities to correlate a mutual influence of the first and the second levels of subjective control in an objective way, to re-build their position in due time. This is a teacher who can really help a student, whom students trust.

In humanistic pedagogy, principles cannot be strict regulators of building an educational process at any educational establishment. They only presuppose its possible variants and are used as "delicate, gentle regulators facilitating the choice of conditions, means, methods and forms of personal potential of self-organization; they initiate the activity of our consciousness for the search of sense of our own conduct and activity in a non-violent way" [5, p. 78].

According to A. Khytorskyi, we can also name the principle of integrity as one of the higher school principles in its full interpretation: neither a new impression nor new knowledge can be interrupted by the other new one until a person comprehends it, processes it, since only a freed mind can perceive and evaluate new impressions and knowledge adequately. It concerns modern technologies of "immersion" when students should not leap from one subject onto the other one like "butterflies", on the other hand, a butterfly will never ever land on a whichever plant.

The principle of personal goal-setting manifests itself in this way: education of each student, each would-be specialist is to proceed taking into consideration student's 
personal goals and tasks. It presupposes implementation of elective or special courses, presence of individual curricula, distance learning, etc.

This principle is organically combined with the principle of student's choice of his/her individual educational trajectory; this is student's right to choose a kind and a topic of his/her creative work, means of achieving a set goal, to create an independent educational trajectory of mastering his/her future profession. The credit and module transfer system of higher education makes the above mentioned possible today.

It is also expedient to mention the principle of metasubject grounds of the educational process in higher education - this is an escape from the frames of ordinary university subjects to the meta-subject level; these are new special meta-subject disciplines which combine separate courses or special courses on a new generalizing

\section{REFERENCES}

1. Bondarevska, Ye. V. (1995). Vvedeniie v pedagogicheskuyu kulturu [Introduction into pedagogical culture]. Rostov na Donu [in Russian].

2. Bondarevska, Ye. V. \& Kulnevich, S. V. (1999). Pedagogika lichnosti $v$ gumanisticheskikh teoriyakh $i$ sistemakh vospitanija [Pedagogics of personality in humanistic theories and systems of education]. Rostov na Donu [in Russian].

3. Goncharenko, S. I. (1997). Ukrainskyi pedahohichnyi slovnyk [Ukrainian pedagogical dictionary]. Kyiv: Lybid [in Ukrainian].

\section{ЛІТЕРАТУРА}

1. Бондаревская Е. В. Введение в педагогическую культуру: уч.пос. / Е. В. Бондаревская. - Ростов н/Д. 1995.

2. Бондаревская Е. В., Кульневич С. В. Педагогика личности в гуманистических теориях и системах воспитания: уч. пос. / Е. В. Бондаревская, С. В. Кульневич. - Ростов н/Д. - 1999.

3. Гончаренко С. I. Український педагогічний словник / С. І. Гончаренко. - Київ : Либідь, 1997.

basis. These meta-disciplines predetermine the future of higher education.

The last principle to be mentioned is the principle of situativity of education, situational and pedagogical support focused on creative students in terms of teaching them in an individual way [8].

\section{Conclusions}

A university teacher's task is to prevent the penetration of anti-humanistic means into the teaching / learning process of higher education with the help of humanistic principles, to demonstrate their failure (those of anti-humanistic ones) in achieving positive outcomes in their future professional activity, to convince would-be professionals of taking themselves as the highest value which will help them to re-orient themselves from the position of a passive reproducing personality into a self-organizing, creative one, into a personality who is able to fill his/her professional activity and life creativity with sense.

4. Kodzhaspyrova, H. M. \& Kodzhaspyrov, A. Yu. (2001). Pedagogicheskiy slovar [Pedagogical dictionary]. Moscow [in Russian].

5. Kulnevich, S. V. (2001). Pedagogika lichnosti ot kontseptsiy do tekhnologiy [Pedagogics of personality from conceptions to technologies]. Rostov na Donu [in Russian].

6. Lavrentieva, T. V. (1998). Pedagogika lichnosti [Pedagogics of personality]. Rostov na Donu [in Russian].

7. Rozanov, V. V. (1990). Sumerki prosveshcheniya [Twilight of Enlightenment]. Moscow: "Pedagogika" [in Russian].

8. Khutorskoy, A. V. (2001). Sovremennaya didaktika [Modern didactics]. Saint Petersburg: "Piter" [in Russian].

4. Коджаспирова Г. М., Коджаспиров А. Ю. Педагогический словарь / Г. М. Коджаспирова, А. Ю. Коджаспиров. - М. - 2001.

5. Кульневич С. В. Педагогика личности от концепций до технологий: уч.пос. - Ростов н/Д. - 2001.

6. Лаврентьева Т. В. Педагогика личности / Т. В. Лаврентьева - М. : Педагогика, 1998.

7. Розанов В. В. Сумерки просвещения / В. В. Розанов. - М. : Педагогика, 1990.

8. Хуторской А. В. Современная дидактика / А. В. Хуторской. - СПб: Питер, 2001.

Алла Михайлівна Богущ, доктор педагогічних наук, професор, дійсний член НАПН Украӥни, завідуюча кафедри теорії та методики дошкільної освіти, Південноукраӥнський національний педагогічний університет імені К. Д. Уиинського, вул. Старопортофранківська, 26, м. Одеса, Украӥна

\section{СУЧАСНИЙ ПІДХІД ДО МОДЕРНІЗАЦІї \\ НАВЧАЛЬНО-ВИХОВНОГО ПРОЦЕСУ ВИЩОЇ ШКОЛИ}

У статті представлено підхід до модернізації навчально-виховного процесу вищої школи в контексті сучасного освітнього простору; розкрито сучасні принципи модернізації навчально-виховного процесу вищої школи: принцип гуманістичного характеру освіти, принцип природовідповідності та природодоцільності, 
принцип духовності життєдіяльності студентів, принцип самоорганізуючої творчості майбутніх професіоналів, принцип суб'єктності та свідомості, принцип комплементарності (доповнення), принцип суб'єктивного контролю, принцип особистісного целепокладання студента, принцип метапредметних основ освітнього процесу вищої школи, принцип ситуативності навчання. Освіта розглядається як продукт соціуму, зміст якого залежить від подій, що відбуваються в державі та за ії межами. Модернізація освітнього простору асоціюється 3 такими процесами, як генерація, інтенсифікація, оптимізація, гуманізація, реформування і модернізація. Запобігання або обмеження проникнення антигуманістичних засобів в навчальний процес вищої школи є одним з основних задач викладача ВНЗ. Конструктивними методами навчання вважається комплекс методичних засобів, спрямованих на формування переконання майбутніх професіоналів сприймати себе як найвищу цінність, що допоможе їм переорієнтувати себе, своє «Я» з позиції пасивного відтворення в позицію самоорганізованої, творчої особистості, яка зможе наповнити сенсом свою професійну діяльність і свою життєву творчість.

Ключові слова: вища школа, принципи, модернізація, студент, викладач.

Submitted on April, 8,.2017

УДК: 378.22: $373.61(043.3)$

DOI: https://doi.org/10.24195/2414-4665-2017-5-4

Олег Олександрович Долюсенков, доктор політичних наук, доцент, завідувач кафедри управління освітніми закладами та державної служби,

Наталія Миколаївна Черненко, доктор педагогічних наук, дочент, в.о. професора кафедри управління освітніми закладами та державної служби, Південноукраїнський національний педагогічний університет імені К. Д. Уиинського, вул. Старопортофранківська, 26, м. Одеса, Украӥна

\section{ОСОБИСТІСНА ГОТОВНІСТЬ КЕРІВНИКІВ ДО УПРАВЛІННЯ РИЗИКАМИ}

У сучасних мінливих ринкових умовах здатність керівника, менеджера прогнозувати $і$ запобігати негативним впливам і досягати мети довгострокових програм розвитку установи, організації, освітнього закладу - важлива складова його компетентності, яку в світі та спеціальній літературі прийнято позначати через понятійний конструкт «готовність до управління ризиками». Метою статті є презентація результатів оцінювання особистісної готовності керівників до управління ризиками. Доведено, щзо стан готовності можна сформувати і розвинути. Будь-яка готовність особистості, зокрема до управління ризиками у професійній діяльності, характеризується мобілізацією ресурсів суб'єкта праці на виконання конкретної діяльності. «Готовність до ризику» тлумачимо як особистісну характеристику, що визначає стратегію поведінки в умовах невизначеності, яка спирається на аналіз ситуації і власних можливостей, виявляється у поведінці, діях і судженнях людини. Визначено показники особистісної готовності керівників до управління ризиками: усвідомлення керівниками необхідності і важливості управління ризиками, наявність мотиваційної настанови до управління ризиками, схильність керівників до ризику, настанова на позитивні зміни, толератність до невизначеності, асертивність, гнучкість мислення. Виявлено важливість і необхідність изілеспрямованої підготовки до управління ризиками як керівників з досвідом роботи, так $і$ майбутніх фахівців, недостатню готовність керівників до управління ризиками та необхідність покращення науково-методичного, інформаційного, матеріально-технічного забезпечення підготовки керівників.

Ключові слова: готовність, особистісна готовність, керівник, ризик, управління ризиками.

\section{Постановка проблеми}

В умовах агресивної конкурентної боротьби на ринку послуг пріоритетного значення для якості роботи установ, організацій, освітніх закладів набуває здатність керівників виявляти нехарактерні для радянської системи підприємницькі компетенції, ціннісні установки та способи дій. Окрім необхідності адекватно визначати напрями розвитку установи, організації, освітнього закладу в умовах нестабільності та невизначеності, відслідковувати коньюнктуру ринку освітніх послуг та оцінювати місце на ньому, керівники вимушені прогнозувати та враховувати можливі нормативно-правові, кадрові, економічні, методичні та інші ризики для існування установи, організації, освітнього закладу.

У сучасних мінливих ринкових умовах здатність керівника, менеджера прогнозувати і запобігати негативним впливам, досягати мети довгострокових програм розвитку установи, організації, освітнього закладу $є$ важливою складовою його компетентності, яку в 